\title{
Caveolin-1 is overexpressed in hypopharyngeal squamous cell carcinoma and correlates with clinical parameters
}

\author{
XUENING ZHAO ${ }^{1}$, GANG YU ${ }^{1}$, XUEMIN YU ${ }^{2}$, JUAN WANG ${ }^{2}$ and XINLIANG PAN ${ }^{2}$ \\ ${ }^{1}$ Department of Comprehensive Health II, Shandong Provincial Hospital Affiliated to Shandong University, Shandong 250021; \\ ${ }^{2}$ Department of Otolaryngology, Qilu Hospital of Shandong University, Jinan, Shandong 250031, P.R. China
}

Received December 4, 2015; Accepted June 10, 2016

DOI: $10.3892 / \mathrm{ol} .2016 .4963$

\begin{abstract}
The present study aimed to identify the role of caveolin-1 (CAV1) in hypopharyngeal squamous cell carcinoma (HSCC) and identify its possible correlation with tumor clinical parameters. Expression of CAV1 was measured using immunohistochemical staining of 66 HSCC samples and 44 samples from morphologically normal tissues adjacent to the carcinomas. Expression of CAV1 in HSCC and paracancerous tissues were 71.2 and $9.5 \%$ respectively. Levels of CAV1 expression were significantly associated with tumor differentiation, tumor-node-metastasis stage and lymph nodes metastasis $(\mathrm{P}<0.05)$. The present study identified that expression of CAV1 in HSCC is significantly higher than in paracancerous tissues, suggesting that this high expression of CAV1 is associated with tumor invasion and metastasis.
\end{abstract}

\section{Introduction}

Hypopharyngeal squamous cell carcinoma (HSCC) is a tumor with the poorest prognosis among all head and neck cancers (1). Advances in surgical techniques and perioperative management have improved survival rates to some extent. However, the overall 5 -year survival rate remains only $30-35 \%(2,3)$, despite the use of multimodal therapy, such as radiotherapy and chemotherapy (4). Furthermore, HSCC patients have a higher risk of developing second primary tumors (5). Therefore, it is important to study factors involved in the biological behavior of HSCC. Improved understanding may provide useful information for predicting patient prognosis and identifying specific molecular targets for novel treatments.

Caveolae are vesicular membrane structures measuring 50-100 nm, which are commonly located in cell plasma

Correspondence to: Dr Xuening Zhao, Department of Comprehensive Health II, Shandong Provincial Hospital Affiliated to Shandong University, 324 Jing wu Street, Jinan, Shandong 250021, P.R. China

E-mail: xueningent@hotmail.com

Key words: hypopharyngeal carcinoma, immunohistochemistry, lymph node metastasis, caveolin-1 membranes (6,7). Caveolin-1 (CAV1) is the most important component of caveolae. It is a multifunctional scaffolding protein with numerous binding partners coded for by a gene located on chromosome 7q31.1. It is also associated with cell surface caveolae and involved in regulating lipid raft domains (8). CAV1 is associated with numerous physiological and pathophysiological processes (9). It is involved in signaling transduction (10), cholesterol homeostasis (11) and vesicular transport (12), as well as tumor oncogenesis and suppression. Therefore, CAV1 may be important in the development of cancer.

Previous studies have identified decreased expression of CAV1 in breast, ovarian and lung cancers, as well as sarcoma (13-17). Therefore, it has been suggested that. CAV1 may inhibit cell growth and reduce tumorigenesis in oncogenically transformed cells and in cancer cells (18-20). However, overexpression of CAV1 has been observed in pancreatic and prostate cancer cells $(21,22)$, suggesting that the exact function of CAV1 may depend on the type of tissue it is expressed in. The aim of the present study was to investigate the specific function of CAV1 in HSCC.

\section{Materials and methods}

Patients and tumor tissues. All complete surgical specimens of HSCC were resected and examined from 66 patients (61 male, 5 female), with a median age of 59.5 years (range, 49-74 years), with no evidence of metastasis to other organs and without prior anticancer treatment. All patients underwent hypo-pharyngeal resection at the Qilu Hospital of Shandong University between January 2013 and August 2015. Forty-four morphologically normal tissues adjacent to the carcinomas were also collected. The resected tissues were immediately fixed with $10 \%$ buffered formalin overnight, snap-frozen in liquid nitrogen and stored at $-80^{\circ} \mathrm{C}$. The specimens were examined histologically after staining with eosin and hematoxylin. The pathological stage was classified according to the tumor-node-metastasis (TNM) classification system of the International Union Against Cancer (23).

Immunohistochemistry. All specimens were dehydrated and embedded in paraffin blocks after resection. Sections were cut to $4-\mu \mathrm{m}$ thickness and placed on poly-L-lysine-coated glass slides. After deparaffinization in graded alcohols and xylene, epitope retrieval was carried out. Target retrieval for activated 
Table I. Association between caveolin-1 expression and clinicopathological variables in the 66 patients.

\begin{tabular}{|c|c|c|c|c|}
\hline \multirow[b]{2}{*}{ Variable } & \multirow[b]{2}{*}{ No. patients } & \multicolumn{2}{|c|}{ Caveolin-1 } & \multirow[b]{2}{*}{ P-value } \\
\hline & & Negative & Positive & \\
\hline Age & & & & $P>0.05$ \\
\hline$\leq 50$ & 32 & 9 & 23 & \\
\hline$>50$ & 34 & 10 & 24 & \\
\hline Gender & & & & $P>0.05$ \\
\hline Male & 61 & 17 & 44 & \\
\hline Female & 5 & 2 & 3 & \\
\hline Site of expression & & & & $\mathrm{P}>0.05$ \\
\hline Pyriform sinus & 53 & 32 & 21 & \\
\hline Posterior wall & 8 & 6 & 2 & \\
\hline Postcricoid area & 5 & 4 & 1 & \\
\hline Histological grade & & & & $\mathrm{P}<0.05$ \\
\hline High & 11 & 9 & 2 & \\
\hline Medium & 31 & 21 & 10 & \\
\hline Low & 24 & 9 & 15 & \\
\hline Clinical stage & & & & $\mathrm{P}<0.05$ \\
\hline I & 9 & 2 & 7 & \\
\hline II & 12 & 4 & 8 & \\
\hline III & 27 & 8 & 19 & \\
\hline IV & 18 & 5 & 13 & \\
\hline Lymph node status & & & & $\mathrm{P}<0.05$ \\
\hline Positive & 49 & 12 & 37 & \\
\hline Negative & 17 & 7 & 10 & \\
\hline
\end{tabular}

CAV1 was performed in $0.01 \mathrm{M}$ sodium citrate buffer ( $\mathrm{pH}$ 6.0) for $20 \mathrm{~min}$ in a microwave at $92-95^{\circ} \mathrm{C}$. Endogenous peroxidase was blocked by immersing the sections in $3 \%$ hydrogen peroxide for $15 \mathrm{~min}$ at room temperature. Sections were washed twice in phosphate-buffered saline (PBS) and incubated with 10\% goat serum (Zhongshan Golden Bridge Biotechnology Co., Beijing, China). Primary anti-CAV1 rabbit polyclonal antibody, (Santa Cruz Biotechnology Inc., Dallas, TX, USA), was immersed in a 1:100 dilution in PBS, and the sections were incubated at $4^{\circ} \mathrm{C}$ for $12 \mathrm{~h}$. PBS was used instead of the primary antibody as a negative control. The polymer is a reagent labeled by peroxidase and conjugated to goat anti-rabbit antibody (Beyotime Institute of Biotechnology, Shanghai, China; cat no. A0208; diluted 1:50). After three additional washes, the sections were incubated with polyvalent biotinylated goat anti-rabbit antibody (Beyotime; cat no. A0277; $1: 100)$ for $1 \mathrm{~h}$ at $37^{\circ} \mathrm{C}$. Sections were washed three times in PBS and incubated with streptavidin-conjugated peroxidase (Zhongshan; cat no. SP-9000) for $30 \mathrm{~min}$. Sections were then visualized by incubation with 3,3-diaminobenzidine (Zhongshan; cat no. ZLI-9019) as a chromogen for $5 \mathrm{~min}$ followed by washing in distilled water. After that, sections were counterstained with Mayer's hematoxylin for $5 \mathrm{~min}$. Immunoreactivity was detected with use of a standard $\mathrm{ABC}$ method. The immunohistochemistry kit used was from Zhongshan Golden Bridge Biotechnology Co. (Beijing, China).

The number of stained cells per 500 cells was ascertained using an Olympus microscope (Olympus Corporation, Tokyo,
Japan) in five visual fields at a magnification of x200. Fields with no stained cells were given a score of 0 ; fields with $>5 \%$ stained cells, 1 ; fields with 5-25\% stained cells, 2 ; fields with $26-50 \%$ stained cells, 3 ; fields with $>50 \%$ stained cells, 4 . The intensity of staining was then graded by comparison with a positive control. The positive control was derived from a male patient with hypopharyngeal carcinoma which was diagnosed with a moderately differentiated HSCC. No staining was given a score of 0 ; weak staining, 1; moderate staining, 2; strong staining, 3 . The expression result was considered negative when the sum of two factors was $\leq 3$. The expression result was considered positive when the sum of two factors was $\geq 4$ (24). The assessment of staining intensity was based on the same positive slides and performed independently by two observers who were blinded to the patients' clinical information. The final result was obtained by consensus between the two observers.

Statistical analysis. The Fisher exact test or chi square test was used to analyze the correlation between the patients' parameters and CAV1 histopathological expression using the statistical software SPSS ver. 13.0 (SPSS Inc., Chicago, IL, USA). P<0.05 was considered to indicate a statistically significant difference.

\section{Results}

Patient clinicopathological parameters. Specimens from 66 patients were included in the current study (61 males and 
5 females). The median patient age was 59.5 years (range, 49-74 years). $32 \%$ of patients (21 patients) had early stage disease, and $74 \%$ patients (44 patients) had metastases in their lymph nodes. Details of tumor pathological parameters are shown in Table I.

Expression of caveolin-1. Immunoreactivity, indicating expression of CAV1, was detected in the cytoplasm and at the cell membrane, and was identified by the presence of stained granular immunoreaction products (Fig. 1). Overexpression of CAV1 was observed in vascular endothelial cells (Fig. 1D). Forty-seven specimens (71.2\%) were immunoreactive for CAV1 indicating high expression, and CAV1 levels at peripheral parts of the cancer cell nests were higher than at the central parts; only four specimens (9.5\%) were immunoreactive in paracancerous tissues. Compared with adjacent tissues, CAV1 protein expression was significantly higher in $\mathrm{HSCC}(\mathrm{P}<0.05)$.

Expression of CAV1 was markedly associated with tumor differentiation grade, TNM stage and lymph nodes metastasis. The CAV1 staining results (Fig. 1) demonstrated a trend of gradually increasing CAV1 intensity as the pathological grading increased. Additionally, CAV1 expression in well-differentiated HSCC was significantly lower than in the group with poorly differentiated HSCC. Expression of CAV1 in patients with lymph node metastasis $(78.7 \%)$ was significantly higher than in patients without metastasis $(58.8 \%, \mathrm{P}<0.05)$. There was no correlation between CAV1 expression with age, gender or site of CAV1 expression $(\mathrm{P}>0.05)$.

\section{Discussion}

Caveolae are a subdomain of lipid rafts that are defined as 'small (50-200 nm) heterogeneous membrane domains enriched in sphingolipids and sterol that are involved in the compartmentalization of various cellular processes' (25). CAV1 is a 21-24 $\mathrm{kDa}$ protein that is an important structural component of caveolae membranes in vivo and participates in transduction processes and vesicular trafficking. It also has a regulatory role in a number of signaling pathways, such as epidermal growth factor receptor, protein kinase C, G-proteins, endothelial nitric oxide synthase (eNOS), and Src family tyrosine kinase, which may induce development of human cancer.

The differential expression of CAV1 is not a novel finding in relation to the neoplastic histotype. As stated previously, downregulation of CAV1 has been identified and reported in a variety of tumors (13-17), however, its overexpression has been identified in other types of tumor $(21,22)$, indicating that the behavior of CAV1 in carcinogenesis may depend on the type of tissue it is expressed in.

The present study suggests that overexpression of CAV1 in HSCC is comparable to that observed in prostate carcinoma. CAV1 overexpression was also identified to correlate with lymph node involvement, TNM stage, Gleason score, and a positive surgical margin. Previous studies have demonstrated that immunoreactivity for CAV1 is an important and independent predictor for disease prognosis in lymph node negative patients with prostate carcinomas (21). Thus, HSCC seems to share common features with prostate carcinoma in CAV1 immunoreactivity.

It is well known that the incidence of HSCC in men is higher than that of women (26). Sex hormones play an important
A

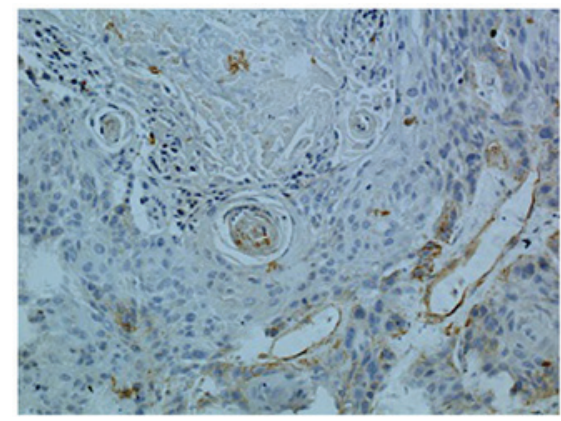

B

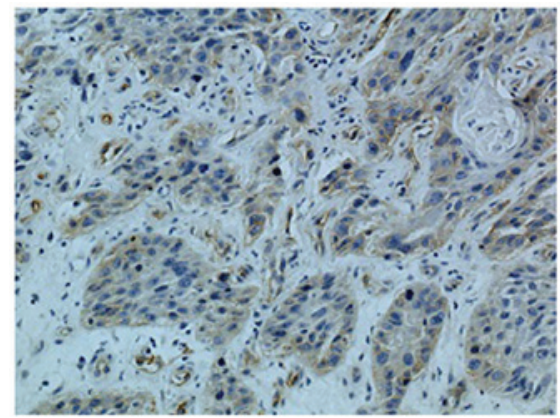

C

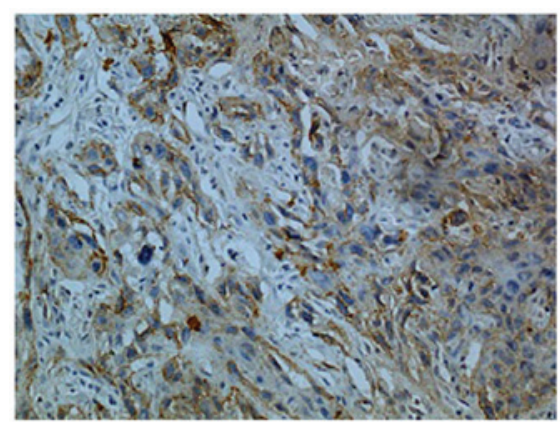

D

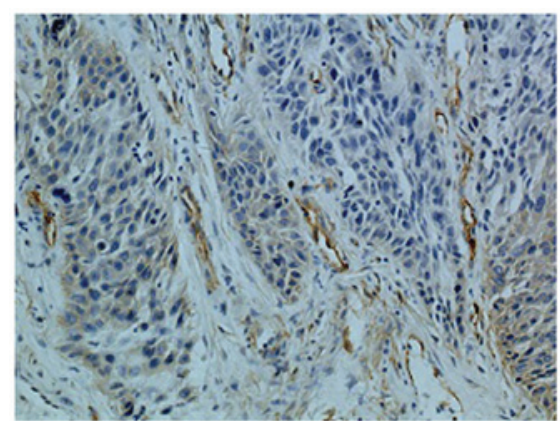

E

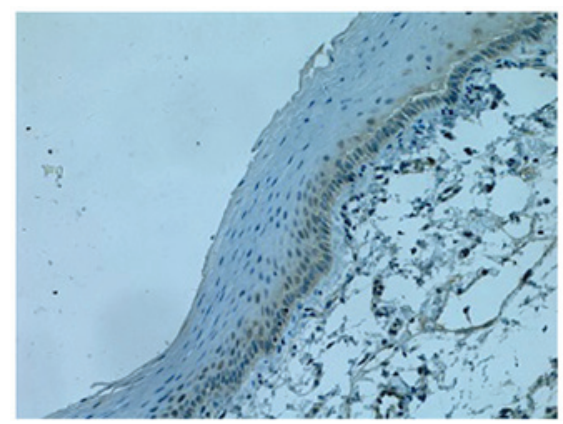

Figure 1. Immunohistochemical staining for CAV1. (A) High-grade differentiated hypopharyngeal squamous cell carcinoma (HSCC), (B) Medium-grade differentiated HSCC, (C) Low-grade differentiated HSCC. The majority of cancer cell cytoplasm was strongly stained for caveolin-1 (CAV1). (D) Overexpression of CAV1 was identified in vascular endothelial cells, (E) Paracancerous tissues. CAV1 expression was predominantly located on the cell membrane of epithelial cells in the basal layer. CAV1 was rarely expressed on the intermediate and the upper layer. Magnification, x200. 
role in this disease. Nuclear estrogen receptor $\alpha$ levels and epidermal growth factor receptor expression are significantly increased in head and neck squamous cell carcinomas (27). Prostate carcinoma growth is androgen dependent. CAV1 mediates testosterone stimulated clonal or survival growth and promotes metastatic activity in prostate carcinoma (28). Additionally, overexpression of CAV1 potentiates ligand-dependent androgen receptor activation (29). Similar mechanisms may be involved in HSCC.

The results of the current study indicate that overexpression of CAV1 may be a marker for poor HSCC cancer prognosis and lymph node metastasis. CAV1 overexpression alone cannot be relied upon to predict lymph node metastases. However, practitioners may use the tumor markers of biopsy specimens to improve current therapeutic strategies. Moreover, overexpression of CAV1 has been identified in vascular endothelial cells. The defects in activation of eNOS with vascular endothelial growth factor (VEGF) stimulation played a role in the inability of $\mathrm{Cav}^{-1}$ mice to stimulate angiogenesis (30). The result was demonstrated in endothelial cells (ECs) from these mice. The ability of $\mathrm{Cav}^{-1}$ ECs to form tubes on Matrigel with VEGF stimulation was significantly lower than that of $\mathrm{Cav}^{+/+} \mathrm{ECs}$. VEGF-induced nitric oxide production was greatly inhibited in $\mathrm{Cav}^{-}$- ECs (30). VEGF-induced phosphorylation of eNOS on Ser1 177 and dephosphorylation on Thr495 were abrogated in $\mathrm{Cav}^{-1}$ ECs but not in $\mathrm{Cav}^{+/+} \mathrm{ECs}$, both of which were considered hallmarks of eNOS activation (30). Thus, the overexpression of CAV1 may play an important role in tumorigenesis of HSCC by positively regulating angiogenesis. Nonetheless, whether this overexpression is a crucial factor requires further study.

In conclusion, the present study demonstrates that CAV1 expression is significantly higher in HSCC than that in paracancerous tissues and is associated with tumor invasion and metastasis.

\section{Acknowledgements}

The present study was supported by the National Natural Science Foundation of China (grant no. 30772411/H1625).

\section{References}

1. Jemal A, Siegel R, Ward E, Murray T, Xu J and Thun MJ: Cancer statistics, 2007. CA Cancer J Clin 57: 43-66, 2007.

2. Hoffman HT, Karnell LH, Shah JP, Ariyan S, Brown GS, Fee WE, Glass AG, Goepfert H, Ossoff RH and Fremgen AM: Hypopharyngeal cancer patient care evaluation. Laryngoscope 107: 1005-1017, 1997.

3. Bova R, Goh R, Poulson M and Coman WB: Total pharyngolaryngectomy for squamous cell carcinoma of hypopharynx: A review. Laryngoscope 115: 864-869, 2005.

4. Godballe C, Jørgensen K, Hansen O and Bastholt L: Hypopharyngeal cancer: Results of treatment based on radiation therapy and salvage surgery. Laryngoscope 112: 834-838, 2002.

5. Dikshit RP, Boffetta P, Bouchardy C, Merletti F, Crosignani P, Cuchi T, Ardanaz E and Brennan P: Risk factors for the development of second primary tumors among men after laryngeal and hypopharyngeal carcinoma. Cancer 103: 2326-2333, 2005.

6. Anderson RG: The caveolae membrane system. Annu Rev Biochem 67: 199-225, 1998.

7. Yamada E: The fine structure of the gall bladder epithelium of the mouse. J Biophys Biochem Cytol 1: 445-458, 1955.

8. Rothberg KG, Heuser JE, Donzell WC, Ying YS, Glenney JR and Anderson RG: Caveolin, a protein component of caveolae membrane coats. Cell 68: 673-682, 1992.
9. Rothberg KG, Heuser JE, Donzell WC, Ying YS, Glenney JR and Anderson RG: Caveolin, a protein component of caveolae membrane coats. Cell 68: 673-682, 1992.

10. Smart EJ, Graf GA, McNiven MA, Sessa WC, Engelman JA, Scherer PE, Okamoto T and Lisanti MP: Caveolins, liquid-ordered domains and signal transduction. Mol Cell Biol 19: 7289-7304, 1999.

11. Pike LJ, Han X, Chung KN and Gross RW: Lipid rafts are enriched in arachidonic acid and plasmenylethanolamine and their composition is independent of caveolin-1 expression: A quantitative electrospray ionization/mass spectrometric analysis. Biochemistry 41: 2075-2088, 2002.

12. Orlandi PA and Fishman PH: Filipin-dependent inhibition of cholera toxin: Evidence for toxin internalization and activation through caveolae-like domains. J Cell Biol 141: 905-915, 1998.

13. Park SS, Kim JE, Kim YA, Kim YC and Kim SW: Caveolin-1 is down-regulated and inversely correlated with HER2 and EGFR expression status in invasive ductal carcinoma of the breast. Histopathology 47: 625-630, 2005.

14. Chen ST, Lin SY, Yeh KT, Kuo SJ, Chan WL, Chu YP and Chang JG: Mutational, epigenetic and expressional analyses of caveolin-1 gene in breast cancers. Int J Mol Med 14: 577-582, 2004.

15. Wiechen K, Sers C, Agoulnik A, Arlt K, Dietel M, Schlag PM and Schneider U: Down-regulation of caveolin-1, a candidate tumor suppressor gene, in sarcomas. Am J Pathol 158: 833-839, 2001.

16. Bélanger MM, Roussel E and Couet J: Caveolin-1 is down-regulated in human lung carcinoma and acts as a candidate tumor suppressor gene. Chest 125 (5 Suppl): 106S, 2004.

17. Wiechen K, Diatchenko L, Agoulnik A, Scharff KM, Schober H, Arlt K, Zhumabayeva B, Siebert PD, Dietel M, Schäfer R and Sers C: Caveolin-1 is down-regulated in human ovarian carcinoma and acts as a candidate tumor suppressor gene. Am J Pathol 159: 1635-1643, 2001.

18. Engelman JA, Wykoff CC, Yasuhara S, Song KS, Okamoto T and Lisanti MP: Recombinant expression of caveolin-1 in oncogenically transformed cells abrogates anchorage-independent growth. J Biol Chem 272: 16374-16381, 1997.

19. Lee SW, Reimer CL, Oh P, Campbell DB and Schnitzer JE: Tumor cell growth inhibition by caveolin re-expression in human breast cancer cells. Oncogene 16: 1391-1397, 1998.

20. Bender FC, Reymond MA, Bron C and Quest AF: Caveolin-1 levels are down-regulated in human colon tumors, and ectopic expression of caveolin-1 in colon carcinoma cell lines reduces cell tumorigenicity. Cancer Res 60: 5870-5878, 2000.

21. Yang G, Truong LD, Wheeler TM and Thompson TC: Caveolin-1 expression in clinically confined human prostate cancer: A novel prognostic marker. Cancer Res 59: 5719-5723, 1999.

22. Suzuoki M, Miyamoto M, Kato K, Hiraoka K, Oshikiri T, Nakakubo Y, Fukunaga A, Shichinohe T, Shinohara T, Itoh T, et al: Impact of caveolin-1 expression on prognosis of pancreatic ductal adenocarcinoma. Br J Cancer 87: 1140-1144, 2002.

23. Sobin LH and Wittekind CH (eds): TNM lassification of head and neck carcinoma. In: International Union Against Cancer. TNM: Classification of Malignant Tumours. Vol 1. 5th edition. Wiley, New York, NY, pp17-50, 1997.

24. Zhao T, Zhu MG and Huang ZY: Comparative study of expression of oncogene protein products in lung cancer. Chinese Journal of Cancer 1: 13-15, 1995.

25. Pike LJ: Rafts defined: A report on the keystone symposium on lipid rafts and cell function. J Lipid Res 47: 1597-1598, 2006.

26. Wang WL, Lee CT, Lee YC, Hwang TZ, Wang CC, Hwang JC, Tai CM, Chang CY, Tsai SS, Wang CP, et al: Risk factors for developing synchronous esophageal neoplasia in patients with head and neck cancer. Head Neck 33: 77-81, 2011.

27. Egloff AM, Rothstein ME, Seethala R, Siegfried JM, Grandis JR and Stabile LP: Cross-talk between estrogen receptor and epidermal growth factor receptor in head and neck squamous cell carcinoma. Clin Cancer Res 15: 6529-6540, 2009.

28. Li L, Yang G, Ebara S, Satoh T, Nasu Y, Timme TL, Ren C, Wang J, Tahir SA and Thompson TC: Caveolin-1 mediates testosterone-stimulated survival/clonal growth and promotes metastatic activities in prostate cancer cells. Cancer Res 61: 4386-4392, 2001.

29. Lu ML, Schneider MC, Zheng Y, Zhang X and Richie JP: Caveolin-1 interacts with androgen receptor. A positive modulator of androgen receptor mediated transactivation. J Biol Chem 276: 13442-13451, 2001.

30. Sonveaux P, Martinive P, DeWever J, Batova Z, Daneau G, Pelat M, Ghisdal P, Grégoire V, Dessy C, Balligand JL and Feron O: Caveolin-1 expression is critical for vascular endothelial growth factor-induced ischemic hindlimb collateralization and nitric oxide-mediated angiogenesis. Circ Res 95: 154-161, 2004. 